\title{
Hilangnya Tes Insolvensi sebagai Syarat Kepailitan di Indonesia
}

\author{
Gede Aditya Pratama \\ Fakultas Hukum, Universitas Bhayangkara Jakarta Raya \\ Email: gede.aditya.pratama@dsn.ubharajaya.ac.id
}

Article info

Received: Dec 30, 2020 Revised: Feb 15, $2021 \quad$ Accepted: Feb 17, $2021 \quad$ Published: Jun 10, 2021

DOI: https://doi.org/10.31599/krtha.v15i1.450

Keywords : bankruptcy, insolvency, debitors, creditors

Abstract : This article aims to explain the missing of insolvency test as one of the bankruptcy conditions in Indonesia. Regulations regarding bankrupty requirements are regulated in the regulations in Indonesia which change from time to time. Until the enactment of Law Number 37 Year 2004 concerning Bankcruptcy and Postponement of Debt Payment Obligations, the insolvency test has not been used as a condition for bankcrupty to determine whether a debtor can be bankcrupt or not. The debtor can be declared bankerrupt only by proving that the debtor has 2 (two) creditors or more, does not pay at least 1 (one) debt, and the debt is due and can be collected. In explaining the missing of insolvency test for bankecruptcy requirements, this article use a normative juridical research method. The data used are secondary data collected by studing documents or library materials. This article explains that the missing of the insolvency test under bankcruptcy conditions in Indonesia can result in a company/debtor that is performing well in financial terms can be bankrupt. This is because the bankruptcy requirements in Indonesia do not consider the debtor's ability to pay his debts. As a result, debtors who have a large assests can be bankrupt by creditors who only have relatively small debt demands.

Kata kunci : Tes insolvensi, syarat kepailitan

Abstrak : Artikel ini bertujuan untuk menjelaskan tes insolvensi yang hilang dalam syaratsyarat kepailitan di Indonesia. Pengaturan mengenai syarat kepailitan diatur dalam peraturan perundangan-undangan di Indonesia yang berubah dari waktu ke waktu. Hingga diundangkannya Undang-Undang Nomor 37 Tahun 2004 tentang Kepailitan dan Penundaan Kewajiban Pembayaran Utang, tes insolvensi masih belum dijadikan sebagai syarat kepailitan untuk menentukan apakah debitur dapat dipailitkan atau tidak. Debitur dapat dinyatakan pailit cukup dengan dibuktikan bahwa debitur tersebut mempunyai 2 (dua) kreditor atau lebih, tidak membayar sedikitnya 1 (satu) utang, dan utang tersebut telah jatuh waktu dan dapat ditagih. Dalam menjelaskan mengenai tes insolvensi yang hilang dalam syarat kepailitan, artikel ini menggunakan metode penelitian yuridis normatif. Data yang digunakan adalah data sekunder yang dikumpulkan dengan studi dokumen atau bahan pustaka. Artikel ini menjelaskan bahwa hilangnya tes insolvensi dalam syarat kepailitan di Indonesia dapat mengakibatkan suatu perusahaan/debitur yang sebenarnya berkinerja keuangan baik dapat dipailitkan. Hal ini dikarenakan syarat kepailitan di Indonesia tidak mempertimbangkan tentang kemampuan debitur dalam membayar utangnya. Sehingga debitur yang mempunyai aset besar dapat 
dipailitkan oleh kreditur yang hanya mempunyai tuntutan utang yang relatif $\mathrm{kecil} / \mathrm{sedikit.}$

\section{PENDAHULUAN}

Para praktisi hukum akhir-akhir ini tentu melihat dengan mata kepala sendiri betapa banyaknya perkara PKPU dan Kepailitan yang diajukan ke Pengadilan Niaga sepanjang tahun 2020 ini. Berdasarkan data yang dikeluarkan oleh SIPP Pengadilan Negeri Jakarta Pusat dalam kurun waktu triwulan terakhir saja di tahun 2020 dari bulan Oktober hingga pertengahan Desember 2020, sudah ada 133 perkara PKPU dan Kepailitan yang masuk ke Pengadilan Niaga Jakarta Pusat. ${ }^{1}$ Hal ini berarti bahwa hanya dalam waktu kurang dari 3 bulan di akhir tahun 2020, jumlah perkara PKPU dan Kepailitan yang masuk sudah melebihi jumlah putusan kepailitan dari tahun 1950 hingga 1996 (46 tahun) yang hanya kurang lebih 130 putusan. $^{2}$

Melihat maraknya permohonan PKPU dan Kepailitan menimbulkan kekhwatiran tersendiri di kalangan dunia usaha, seolah-olah begitu mudahnya seorang debitur di Indonesia diajukan atau dinyatakan pailit. Pemerintah sendiri bersama-sama dengan DPR menyikapi fenomena ini dengan berinisiatif untuk memperketat syarat pengajuan pailit agar tidak terkesan bahwa di Indonesia itu orang atau suatu badan usaha dengan mudahnya dapat dipailitkan. Dinyatakan bahwa dikarenakan begitu mudahnya orang digugat pailit maka dalam RUU Kepailitan dan PKPU, kini akan ditambahkan syarat minimal utang debitur sebesar Rp. 1.000.000.000,- (satu miliar Rupiah). ${ }^{3}$

Apakah penambahan syarat minimal utang ini memang adalah jawaban dari begitu maraknya permohonan kepailitan di Indonesia atau sebenarnya ada yang harus diperbaiki dari norma hukum syarat-syarat kepailitan di Indonesia? Kita ketahui bahwa norma hukum kepailitan di Indonesia telah mengalami beberapa perubahan semenjak zaman Hindia Belanda yaitu dengan dikeluarkannya Faillissement-Verordening Staatsblad 1905 Nomor 217 juncto Staatsblad 1906 Nomor 348 yang mulai berlaku sejak 1 November 1906 (“Faillissement-Verordening 1906”), Perpu Nomor 1 Tahun 1998 tentang Kepailitan yang kemudian ditetapkan menjadi Undang-Undang Nomor 4 Tahun 1998 tentang

1 Sistem Informasi Penelusuran Perkara Pengadilan Negeri Jakarta Pusat, http://sipp.pnjakartapusat.go.id/statistik_perkara, diakses 14 Desember 2020.

${ }^{2}$ Hadi Shubhan, Hukum Kepailitan Prinsip, Norma, dan Praktik di Pengadilan, cet. 6 (Jakarta: Kencana Prenadamedia Group, 2019), hlm. 6.

3 Detiknews, RUU Kepailitan Perketat Syarat Pailit, Minimal Utang Debitur Rp 1M, https:// news.detik.com/berita/d-5272385/ruu-kepailitan-perketat-syarat-pailit-minimal-utang-debitur-rp1-m/2, diakses 14 Desember 2020. 
Kepailitan (“UU No. 4/1998”). Peraturan terbaru yang mengatur tentang Kepailitan ini adalah Undang-Undang Nomor 37 Tahun 2004 tentang Kepailitan dan Penundaan Kewajiban Pembayaran Utang ("UU No. 37/2004”).

Apabila kita melihat dari perubahan-perubahan undang-undang tersebut terutama dalam norma yang mengatur mengenai syarat kepailitan khususnya di Pasal 1 ayat (1) Faillissement-Verordening 1906, terlihat bahwa ada yang berubah dalam syarat-syarat kepailitan sebagaimana diatur dalam Pasal 1 ayat (1) UU No. 4/1998 dan Pasal 2 ayat (1) UU No. 37/2004, yaitu hilangnya tes insolvensi sebagai syarat kepailitan. Padahal tes insolvensi menjadi penting dalam syarat kepailitan untuk menentukan apakah debitur tersebut memang benar dalam keadaan insolven atau keadaan tidak mampu membayar utang-utangnya, sehingga memang layak dipailitkan. Syarat kepailitan yang terlalu longgar akan mengakibatkan debitur menjadi mudah dipailitkan meskipun sebenarnya debitur tersebut mempunyai nilai aset yang jauh lebih besar dibandingkan dengan jumlah utang yang dituntut oleh kreditur. Terlalu mudahnya suatu badan usaha/debitur untuk dipailitkan tentu akan berakibat buruk bagi perkenomian suatu negara dan ketidaknyamanan bagi investor ketika ingin berinvestasi di negara tersebut. Dalam artikel ini kita akan membahas apa yang dimaksud dengan tes insolvensi dan bagaimana tes insolvensi seharusnya digunakan untuk menentukan apakah seorang debitur dapat dipailitkan atau tidak.

\section{II.METODE PENELITIAN}

Artikel ini menggunakan metode penelitian yuridis normatif yang bersumber dari studi kepustakaan. ${ }^{4}$ Metode ini digunakan untuk menjawab permasalahan-permasalahan yang muncul dalam penelitian ini yang tidak terlepas dari kebutuhan akan data yang dapat dipenuhi dengan pencarian bahan berupa buku atau tulisan-tulisan lainnya. Yuridis normatif berarti penelitian ini mengacu pada norma hukum yang terdapat dalam peraturan perundang-undangan dan keputusan pengadilan beserta norma-norma yang berlaku dan mengikat masyarakat. ${ }^{5}$ Tipe penelitian yang digunakan dalam penelitian ini adalah tipe penelitian deskriptif karena dimaksudkan untuk memberikan data yang seteliti mungkin tentang manusia, keadaan, atau gejala lainnya. ${ }^{6}$

\footnotetext{
${ }^{4}$ Serjono Soekanto dan Sri Mamudji, Penelitian Hukum Normatif (Suatu Tinjauan Singkat), Cet. 8, (Jakarta: PT Raja Grafindo Persada, 2004), hlm. 29.

5 Sri Mamudji, et.al., Metode Penelitian dan Penulisan Hukum, (Jakarta: Badan Penerbit Fakultas Hukum Universitas Indonesia, 2005), hlm. 9-10.

${ }^{6}$ Serjono Soekanto dan Sri Mamudji, Penelitian Hukum Normatif (Suatu Tinjauan Singkat), Cet. 8, (Jakarta: PT Raja Grafindo Persada, 2004), hlm. 34.
} 
Jenis data yang digunakan dalam penelitian ini adalah jenis data sekunder. Jenis data sekunder adalah data yang tidak diperoleh langsung dari lapangan melainkan diperoleh dari studi kepustakaan atau studi literatur. ${ }^{7}$ Data sekunder ini terdiri dari bahan hukum primer, sekunder, dan tersier. Bahan hukum primer yaitu bahan-bahan hukum yang mengikat. Bahan hukum primer antara lain berupa hukum tertulis seperti peraturan perundang-undangan serta putusan pengadilan. Penelitian ini dilakukan dengan cara mengkaji dan menganalisis bahan hukum primer yaitu Faillissement-Verordening 1906, UU No. 4/1998, dan UU No. 37/2004, serta putusan pengadilan niaga. Bahan hukum sekunder adalah bahan-bahan yang memberikan penjelasan mengenai bahan hukum primer. ${ }^{8}$ Untuk menjelaskan bahan hukum primer tersebut digunakan bahan hukum sekunder seperti buku-buku, jurnal ilmiah, artikel-artikel dari surat kabar, dan internet. Bahan hukum tersier yaitu petunjuk terhadap bahan hukum primer dan sekunder seperti kamus dan ensiklopedia. ${ }^{9}$ Pengumpulan data dalam penelitian ini dilakukan dengan studi dokumen atau bahan pustaka yang merupakan pengumpulan data yang dilakukan melalui data tertulis dengan menggunakan "content analysis". ${ }^{10}$

\section{PEMBAHASAN}

\section{A. Syarat-syarat Kepailitan di Indonesia berdasarkan UU No. 37/2004}

Pasal 2 ayat (1) UU No. 37/2004 mengatur syarat-syarat kepailitan yang dianut di Indonesia saat ini yaitu: (a) debitur mempunyai 2 (dua) kreditor atau lebih; (b) tidak membayar lunas sedikitnya 1 (satu) utang; dan (c) utang tersebut telah jatuh waktu dan dapat ditagih. Syarat yang pertama yaitu debitur mempunya 2 (dua) kreditor atau lebih, ini sesuai dengan asas concursus creditorium, yang berarti bahwa debitur harus memiliki lebih dari satu kreditur. ${ }^{11} \mathrm{Hal}$ ini tentu logis, karena apabila debitur hanya memiliki 1 (satu) kreditur saja maka seharusnya tidak ada kekhawatiran dari kreditur itu sendiri bahwa dia tidak akan mendapatkan bagian pelunasan hutang dari aset-aset yang dimiliki oleh debitur.

Mekanisme kepailitan ada untuk menghindari benturan atau konflik antara beberapa kreditur yang hendak berebut aset milik debitur yang akan digunakan sebagai

\footnotetext{
${ }^{7}$ Ibid., hlm. 28.

${ }^{8}$ Ibid., hlm. 52.

${ }^{9}$ Ibid., hlm. 33.

${ }^{10}$ Soerjono Soekanto, Pengantar Penelitian Hukum, (Jakarta: Penerbit Universitas Indonesia, 2008),

11 Sutan Remy Sjahdeni, Sejarah, Asas, dan Teori Hukum Kepailitan, cet. 2, (Jakarta: Prenadamedia
} hlm. 21. Group, 2018), hlm. 163. 
jaminan pelunanasan hutangnya. Apabila itu yang terjadi tentu akan merugikan si kreditur itu sendiri, karena yang terjadi adalah "siapa cepat dia dapat”. Kreditur yang cepat mengajukan gugatan dan mengeksekusi aset debitur-lah yang akan mendapat pelunasan hutangnya, sedangkan kreditur yang terlambat mengajukan gugatan akan tertinggal dan mendapatkan sisa aset debitur dari apa yang telah diperoleh kreditur sebelumnya. Untuk itulah ada mekanisme kepailitan agar aset-aset debitur dapat dibagi kepada para kreditur sesuai dengan prinsip pari passu prorata parte $^{12}$.

Dalam syarat yang pertama ini tidak dipersyaratkan rasio hutang kreditor tersebut terhadap total nilai aset dari si debitur, yang penting setidak-tidaknya harus memiliki 2 kreditur. Sehingga dapat dikatakan meskipun suatu perusahaan sebagai debitur memiliki nilai total aset sebesar Rp. 1.000.000.000.000,- (satu triliun Rupiah) dan si kreditur masingmasing hanya memiliki tagihan sebesar Rp. 1.000.000 (satu juta Rupiah), maka si kreditur tetap dapat mengajukan permohonan pailit terhadap si debitur.

Syarat yang kedua adalah tidak membayar lunas sedikitnya 1 (satu) utang. Dalam hal ini berarti bahwa dari 2 (dua) atau lebih kreditur tersebut, cukup sedikitnya hanya 1 (satu) utang saja kepada salah satu kreditur yang tidak dibayar, meskipun utang kepada kreditur lainnya lancar dibayarkan. Tidak diperhitungkan juga nilai dari utang yang belum dibayarkan kepada 1 (satu) kreditur tersebut terhadap total dari nilai utang yang dimiliki oleh debitur.

Sebagai contoh bisa saja seorang debitur dimohonkan pailit atas hutang sebesar Rp. 1.000.000,- (satu juta Rupiah) yang tidak dibayarkan kepada salah satu kreditur, padahal si debitur memiliki total utang dengan nilai Rp. 1.000.000.000,- (satu miliar Rupiah), yang mana terhadap sisa utang sebesar Rp. 999.000 .000 (sembilan ratus sembilan puluh sembilan juta Rupiah) terhadap kreditur-kreditur lainnya masih lancar pembayarannya. Tidak dipersyaratkan juga alasan kenapa si debitur tidak membayar utang tersebut, apakah karena memang tidak mampu membayar atau karena tidak mau membayar. Karena bisa saja debitur tidak membayar utang karena memang tidak mau membayar bukan karena tidak mampu membayar, sebagai contoh debitur tidak membayar utang kepada kreditur karena ada juga prestasi dari kreditur yang belum dilaksanakan kepada debitur.

Syarat yang ketiga adalah utang tersebut telah jatuh waktu dan dapat ditagih.

12 Prinsip pari passu prorata parte berarti bahwa harta kekayaan debitor merupakan jaminan bersama untuk pelunasan hutang kepada para kreditor dan hasilnya harus dibagikan secara proporsional antara para kreditor, kecuali jika antara para kreditor tersebut menurut undang-undang ada yang harus didahulukan dalam menerima pembayaran tagihannya. Lihat ${ }^{12}$ Hadi Shubhan, Hukum Kepailitan Prinsip, Norma, dan Praktik di Pengadilan, cet. 6 (Jakarta: Kencana Prenadamedia Group, 2019), hlm. 29. 
Penjelasan Pasal 2 ayat (1) UU No. 37/2004, hanya menjelaskan bahwa utang yang telah jatuh waktu dan dapat ditagih sebagai berikut:

"Yang dimaksud dengan "utang yang telah jatuh waktu dan dapat ditagih" adalah kewajiban untuk membayar utang yang telah jatuh waktu, baik karena telab diperjanjikan, karena percepatan waktu penagibannya sebagaimana diperjanjikan, karena pengenaan sanksi atau denda oleh intansi yang berwenang, maupun karena putusan pengadilan."

Sebagai contoh dalam suatu perjanjian telah dinyatakan bahwa pembayaran utang harus dilakukan dalam suatu kurun waktu tertentu (due date) atau ada putusan pengadilan yang menyatakan bahwa debitur harus memberikan sejumlah uang kepada kreditur baik karena adanya wanprestasi maupun atas putusan ganti rugi terhadap suatu perbuatan melawan hukum yang dilakukan si debitur kepada kreditur, itu dapat dikatakan sebagai utang yang telah jatuh waktu dan dapat ditagih.

\section{B. Tes Insolvensi sebagai Syarat Kepailitan}

Norma atau pengaturan mengenai syarat-syarat kepailitan yang dianut suatu negara adalah penting dan sangat mempengaruhi perekonomian di suatu negara. Apabila syarat-syarat kepailitan tersebut terlalu longgar maka akan sangat mudah suatu badan usaha di negara tersebut untuk dimohonkan pailit yang mengakibatkan para pelaku usaha dan investor menjadi takut untuk berusaha atau menanamkan modalnya di negara tersebut. Terlebih, lembaga kepailitan itu sendiri dapat disalahgunakan dari yang awalnya sebagai lembaga untuk membereskan permasalahan pembayaran utang yang menimpa debitur dan kreditur, menjadi sarana untuk mengancam debitur untuk segera melunasi utangnya sesuai kehendak kreditur apabila tidak ingin dipailitkan.

Sebenarnya salah satu asas universal yang ada dalam hukum kepailitan di seluruh dunia adalah bahwa hanya debitor yang telah insolven saja yang dapat dinyatakan pailit oleh pengadilan. ${ }^{13}$ Insolven sendiri adalah suatu keadaan dari si debitur, yang mana nilai dari seluruh utang debitur melebihi nilai dari seluruh aset yang dimiliki debitur tersebut. ${ }^{14}$ Untuk mengetahui apakah debitur telah insolven maka perlu untuk dilakukan tes insolvensi terhadap debitur tersebut. Keberadaan tes insolvensi ini sebenarnya sudah diatur sebelumnya dalam Pasal 1 ayat (1) Faillissement-Verordening 1906, yang berbunyi sebagai berikut:

"Setiap debitur (orang yang berutang) yang tidak mampu membayar utangnya yang berada dalam keadaan berhenti membayar kembali utang tersebut, baik atas permintaannya sendiri

13 Sutan Remy Sjahdeni, Sejarah, Asas, dan Teori Hukum Kepailitan, cet. 2, (Jakarta: Prenadamedia Group, 2018), hlm. 151.

${ }^{14}$ Ibid., hlm. 153. 
maupun atas permintaan seorang keditur (orang yang berpiutang) atau beberapa orang krediturnya, dapat diadakan putusan oleh bakim yang menyatakan bahwa debitur yang bersangkutan dalam keadaan pailit."

Berdasarkan Pasal 1 ayat (1) Faillissement-V erordening 1906, hanya debitur yang tidak mampu membayar utangnya saja yang dapat dinyatakan pailit. Seorang debitur dapat diketahui tidak mampu membayar utangnya, hanya apabila terhadapnya telah dilakukan tes insolvensi. Kondisi tidak mampu membayar utang (insolven) adalah kondisi pada saat nilai dari seluruh aset yang dimiliki oleh debitur tersebut masih lebih kecil dibandingkan dengan total utang yang dimilikinya terhadap para kreditur. Sehingga rumus-nya adalah sebagai berikut:

\section{total aset $<$ total utang $=$ insolven}

Sehingga tes insolvensi dilakukan untuk mengetahui apakah total aset debitur lebih besar atau lebih kecil dari nilai seluruh hutang yang dimiliki oleh debitur tersebut (balance sheet insolvency). Apabila total nilai hutang debitur lebih besar dari seluruh nilai aset yang dimilikinya, tentu debitur dalam keadaan tidak mampu membayar utang-utang nya kepada para kreditur, karena sekalipun seluruh aset debitur dijual tetap tidak dapat melunasi seluruh utangnya kepada para kreditur. Tes insolvensi ini dapat dilakukan oleh akuntan publik/auditor independen yang ditunjuk oleh debitur dan kreditur, atau apabila debitur dan kreditur tidak dapat menyepakati auditor mana yang akan ditunjuk, maka pengadilan dapat menunjuk auditor tersebut. Dengan tes insolvensi ini maka dapat diketahui apakah debitur dalam keadaan "tidak mampu membayar" (insolven) atau tidak terhadap hutang-hutangnya kepada para kreditur.

Namun, baik dalam UU No. 4/1998 maupun UU No. 37/2004, tes insolvensi ini tidak lagi menjadi syarat untuk mempailitkan debitur, sehingga cukup apabila debitur tersebut mempunyai 2 (dua) kreditor atau lebih, tidak membayar lunas sedikitnya 1 (satu) utang, dan utang tersebut telah jatuh waktu dan dapat ditagih, maka debitur tersebut dapat dinyatakan pailit. Dalam Pasal 178 ayat (1) UU No. 37/2004, keadaan insolvensi baru ditentukan setelah debitur dinyatakan pailit, yaitu apabila pada saat rapat pencocokan piutang, debitur tidak menawarkan rencana perdamaian, rencana perdamaian yang ditawarkan tidak diterima, atau pengesahan perdamaian ditolak berdasarkan putusan yang telah memperoleh kekuatan hukum tetap. Penilaian terhadap keadaan insolvensi sebagaimana diatur dalam UU No. 37/2004 ini berbeda dengan tes insolvensi yang seharusnya dilakukan di awal sebagai syarat untuk menentukan apakah debitur dapat dipailitkan. Syarat kepailitan dalam UU No. 4/1998 maupun UU No. 37/2004 tidak 
mempertimbangkan tentang kemampuan debitur dalam membayar utangnya. Hal ini mengakibatkan kreditur dengan jumlah tuntutan utang yang relatif kecil/sedikit dapat mengajukan permohonan pailit terhadap debitur yang mempunyai aset jauh lebih besar dibandingkan dengan utang yang harus dibayar kepada kreditur yang mengajukan permohonan pailit tersebut. ${ }^{15}$

Penulis berpendapat bahwa inilah salah satu penyebab maraknya perusahaan/debitur yang dimohonkan PKPU dan pailit akhir-akhir ini, karena kepailitan sekarang menjadi sarana untuk menagih utang secara cepat, mengingat jangka waktu pemeriksaan perkara yang sudah ditentukan dalam undang-undang. Padahal apabila debitur belum dalam keadaan insolven maka seharusnya bukan mekanisme kepailitan di pengadilan niaga yang ditempuh oleh kreditur, melainkan adalah mekanisme gugatan wanprestasi yang menuntut pelunasan utang (prestasi) dari debitur kepada kreditur di pengadilan negeri atau dengan kata lain ini adalah sengketa keperdataan umum. Hal ini dikarenakan sebenarnya debitur masih dalam keadaan solven atau keadaan mampu membayar utangnya.

\section{Kasus Kepailitan Telkomsel}

Salah satu contoh kasus yang menghebohkan Indonesia adalah kepailitan dari salah satu perusahaan jasa telekomunikasi terbesar di Indonesia yaitu PT. Telekomunikasi Seluler (Telkomsel). Telkomsel dipailitkan atas dasar utang yang relatif kecil nilainya apabila dibandingkan dengan nilai total aset yang dimilikinya. Pemohon pailit dalam perkara Telkomsel yaitu PT. Prima Jaya Informatika memiliki nilai tagihan (outstanding) sebesar Rp. 5.260.000.000 (lima milyar dua ratus enam puluh juta Rupiah), serta tagihan pada kreditor lainnya yaitu PT. Estent Media Indonesia sebesar Rp. 40.326 .213 .794 (empat puluh milyar tiga ratus dua puluh enam juta dua ratus tiga belas ribu tujuh ratus sembilan puluh empat Rupiah). Total tagihan yang diajukan oleh pemohon pailit dan kreditur lainnya dalam perkara tersebut jauh dibawah nilai aset yang dimiliki oleh Telkomsel, karena berdasarkan laporan keuangan yang telah diaudit pada tahun 2011, sebagai termohon pailit, Telkomsel sebenarnya membukukan keuntungan (profit) sebesar Rp. 12.823.670.058.017,-- (dua belas triliun delapan ratus dua puluh tiga miliar enam ratus tujuh puluh juta lima puluh delapan ribu tujuh belas Rupiah). Selisih nilai utang yang begitu kecil dibandingkan dengan profit yang begitu besar yang diperoleh Telkomsel tetap tidak menghalangi Majelis Hakim pada

15 Tata Wijayanta, "Kajian Tentang Pengaturan Syarat Kepailitan Menurut Undang-Undang Nomor 37 Tahun 2004”, Mimbar Hukum, Vol. 26, No. 1. 
Pengadilan Niaga Jakarta Pusat untuk mempailitkan Telkomsel melalui Putusan No. 48/PAILIT/2012/PN.NIAGA.JKT.PST, meskipun akhirnya putusan tersebut dibatalkan di tingkat kasasi oleh Mahkamah Agung melalui Putusan No. 704 K/Pdt.Sus/2012.

Sebenarnya kasus ini dan beberapa kasus-kasus lainnya yang terjadi di pengadilan niaga di Indonesia, harusnya menjadi pelajaran berharga dan pengingat bagi para pembentuk undang-undang tentang betapa rentannya suatu perusahaan yang sebenarnya memiliki kinerja keuangan yang baik untuk dapat dipailitkan di Indonesia. Apabila hal ini terus dibiarkan tentu akan dapat menganggu perekonomian di Indonesia, karena para pelaku usaha akan terus berada di bawah bayang-bayang kepailitan yang syaratnya terlalu longgar berdasarkan hukum kepailitan yang berlaku di Indonesia saat ini.

\section{KESIMPULAN}

Untuk melindungi para pelaku usaha dan menjaga stabilitas perekonomian di Indonesia maka syarat kepailitan harus dapat melindung tidak hanya kepentingan dari para kreditur akan tetapi juga kepentingan dari debitur. Dalam hal ini tes insolvensi menjadi penting untuk menentukan apakah debitur tersebut memang dalam keadaan insolven yaitu keadaan tidak mampu membayar utang-utangnya dikarenakan total nilai utangnya sudah lebih besar dari nilai seluruh asetnya, sehingga sedikit harapan bagi debitur untuk dapat melunasi utang-utangnya. Apabila ternyata debitur tersebut masih dalam keadaan solven atau masih dalam keadaan dapat membayar utang-utangnya, maka debitur tersebut tidak dapat dinyatakan pailit, sehingga mekanisme yang seharusnya ditempuh kreditur dalam menuntut pelunasan utang atau pemenuhan prestasi dari debitur adalah mekanisme gugatan perdata di peradilan umum dan bukan mekanisme kepailitan di pengadilan niaga.

\section{SARAN}

Perlu untuk melakukan perubahan terhadap norma syarat-syarat kepailitan yang ada dalam UU No. 37/2014 saat ini, yaitu dengan menambahkan syarat tes insolvensi, yang mana hanya debitur yang telah insolven saja atau berada dalam keadaaan tidak mampu membayar yang dapat dinyatakan pailit oleh pengadilan. Tes insolvensi dapat dilakukan dengan menugaskan akuntan publik/auditor independen pada saat pemeriksaan perkara untuk memeriksa kondisi keuangan dari debitur, apakah nilai seluruh aset yang dimiliki oleh debitur masih lebih besar atau ternyata lebih kecil dari total nilai utang yang dimilikinya (balance sheet insolvency). 


\section{DAFTAR PUSTAKA}

\section{Buku}

Mamudji, Sri. et al. Metode Penelitian Hukum Normatif Suatu Tinjauan Singkat. Jakarta: Badan Penerbit Fakultas Hukum Universitas Indonesia, 2005.

Sjahdeni, Sutan Remy. Sejarah, Asas, dan Teori Hukum Kepailitan. Jakarta: Prenadamedia Group, 2016.

Shubhan, Hadi. Hukum Kepailitan, Prinsip, Norma, dan Praktik di Pengadilan. Jakarta: Kencana Prenadamedia Group, 2019.

Soekantor, Soerjono. Pengantar Penelitian Hukum. Jakarta: Penerbit Universitas Indonesia, 2008.

Soekanto, Soerjono dan Sri Mamudji. Penelitian Hukum Normatif Suatu Tinjauan Singkat. Cet.8. Jakarta: PT Raja Grafindo Persada, 2004.

\section{Jurnal}

Wijayanta, Tata, "Kajian Tentang Pengaturan Syarat Kepailitan Menurut Undang-Undang Nomor 37 Tahun 2004”, Mimbar Hukum, Vol. 26, No. 1.

\section{Peraturan perundang-undangan}

Faillissement-Verordening Staatsblad 1905 Nomor 217 juncto Staatsblad 1906 Nomor 348.

Perpu Nomor 1 Tahun 1998 tentang Perubahan atas Undang-Undang tentang Kepailitan yang ditetapkan menjadi undang-undang dengan Undang-Undang Nomor 4 Tahun 1998 tentang Penetapan Peraturan Pemerintah Pengganti Undang-Undang Nomor 1 Tahun 1998 tentang Perubahan atas Undang-Undang Kepailitan menjadi Undang-Undang.

Undang-Undang Nomor 37 Tahun 2004 tentang Kepailitan dan Penundaan Kewajiban Pembayaran Utang.

\section{Internet}

Sistem Informasi Penelusuran Perkara Pengadilan Negeri Jakarta Pusat, http://sipp.pnjakartapusat.go.id/statistik_perkara. Diunduh 14 Desember 2020.

Detiknews, RUU Kepailitan Perketat Syarat Pailit, Minimal Utang Debitur Rp 1M, https://news.detik.com/berita/d-5272385/ruu-kepailitan-perketat-syarat-pailitminimal-utang-debitur-rp-1-m/2. Diunduh 14 Desember 2020.

\section{Putusan Pengadilan}

PN Jakarta Pusat, Putusan No. 48/PAILIT/2012/PN.NIAGA.JKT.PST. 14 September 2012.

Mahkamah Agung, Putusan No. 704 K/Pdt.Sus/2012. 21 November 2012. 